Journal of Applied Biology \& Biotechnology Vol. 5 (02), pp. 110-117, March-April, 2017

Available online at http://www.jabonline.in

DOI: $10.7324 / \mathrm{JABB} .2017 .50218$

(c) $\mathrm{BY}-\mathrm{NC}-\mathrm{SA}$

\title{
Assessment of genetic diversity in Shorea robusta: an economically important tropical tree species
}

\author{
Giridara-Kumar Surabhi ${ }^{1 *}$, Subhankar Mohanty ${ }^{1}$, Rajesh Kumar Meher ${ }^{1}$, Arup Kumar Mukherjee ${ }^{2}$, \\ Lakshmi Narayana R.Vemireddy ${ }^{3}$ \\ ${ }^{1}$ Regional Plant Resource Centre, Bhubaneswar 751015, Odisha, India. \\ ${ }^{2}$ National Rice Research Institute, Cuttack 753006, Odisha, India. \\ ${ }^{3}$ Regional Agricultural Research Station, Acharya N.G. Ranga Agricultural University, Tirupati 517502, Andhra Pradesh, India.
}

\begin{tabular}{|c|c|}
\hline ARTICLE INFO & ABSTRACT \\
\hline $\begin{array}{l}\text { Article history: } \\
\text { Received on: } 30 / 01 / 2017 \\
\text { Accepted on: } 25 / 02 / 2017 \\
\text { Available online: } 20 / 03 / 2017\end{array}$ & $\begin{array}{l}\text { The present investigation reports an elucidation of genetic diversity among four-populations of most } \\
\text { economically and ecologically important tree species, sal (Shorea robusta Gaertn.) for the first time in India, } \\
\text { using ISSR markers. A total of one-hundred individual S. robusta trees were sampled from four different } \\
\text { populations, considering twenty-five individuals from each population. In total, twenty-ISSR primers were }\end{array}$ \\
\hline $\begin{array}{l}\text { Key words: } \\
\text { AMOVA; genetic diversity; } \\
\text { ISSR; molecular marker; } \\
\text { polymorphism; Shorea robusta. }\end{array}$ & $\begin{array}{l}\text { screened with } S \text {. robusta DNA, and out of twenty, sixteen-primer produced reproducible amplicons. Sixteen } \\
\text { selected ISSR markers were amplified a total of } 118 \text { alleles and the total number of amplicons for individual } \\
\text { primers ranged from } 5 \text { to } 12 \text {, with a mean of } 7.37 \text { alleles per primer, of which } 74 \text { were polymorphic with an } \\
\text { average of } 4.62 \text { alleles per primer. The ISSR primer }(\mathrm{GA})_{8} \text { YG yielded highest number of alleles (12) and } \\
\text { primers (CA) }{ }_{8} \text { RG and }(\mathrm{CT})_{8} \mathrm{G} \text { yielded lowest number of alleles }(5) \text {, with an average alleles size between } 200- \\
\left.3500 \text { bp. The percentage of polymorphic alleles ranged from } 40\left[(\mathrm{CA})_{8} \mathrm{RG}\right] \text { to } 83.33 \text { [(AC) }{ }_{8} \mathrm{C}\right] \text {. A dendrogram } \\
\text { based on UPGMA analysis grouped the four populations into two major clusters, having Keonjhar population } \\
\text { into first cluster and rest three populations into second cluster. It was notable that the second major cluster } \\
\text { was further divided into three-separate sub-clusters, representing population from each three locations. } \\
\text { Analysis of molecular variance (AMOVA) revealed that the majority of genetic variation exists within } \\
\text { populations, compared to the variation that exists among the populations. The present study is a clear-cut } \\
\text { indication that inter- and intra-population genetic variation exists in } S \text {. robusta and ISSRs appears to be an } \\
\text { efficient marker system in quantifying genetic variability in different populations of } S \text {. robusta. }\end{array}$ \\
\hline
\end{tabular}

\section{INTRODUCTION}

Trees are major components of forests/ wild and essential for maintaining health of several ecosystems. Sal (Shorea robusta Gaertn.) is a tropical tree species belonging to the Dipterocarpaceae which consists of three sub-families, 17 genera and $511 \mathrm{spp}$. [1]. It is a hermaphrodite species which attains a height up to $30-35 \mathrm{~m}$ and trunk (girth) diameter of up to $2.0-2.5 \mathrm{~m}$. The species is naturally found in Bhutan, Bangladesh, Nepal and India, and covers more than 12 million hectares of forest area [2], and is economically and ecologically important in that region.

* Corresponding Author

Giridara-Kumar Surabhi, Regional Plant Resource Centre,

Bhubaneswar 751015, Odisha, India. Email: surabhigk@ gmail.com
Champion and Seth [3] have demarcated the distribution of $S$. robusta forests ranging from Uttarakhand in the north up to Andhra Pradesh in the south and Tripura in the east; covering Himachal Pradesh, Haryana, Uttar Pradesh, Bhihar, West Bengal, Odisha, Madya Pradesh, Chattisgarh, Maharastra, Jharkhand, Sikkim, Assam and Meghalaya. In wetter areas, it is evergreen; in drier areas, it is dry-deciduous, shedding most of the leaves in between February to April, leafing out again in April and May. Other Shorea species are insect-pollinated and wind is the exclusive pollen vector in $S$. robusta [4]. Seeds of $S$. robusta are ovoid in shape ( $\sim 8 \mathrm{~mm}$ in diameter), weighing up to $2 \mathrm{~g}$, with two shorter and three longer wings [5] Seed dispersal is wind-driven and seeds of $S$. robusta are recalcitrant, viability is lost within a week after falling to the ground [2]. 
Though the plants produce flowers and fruits luxuriantly in the plains and foothills, its overall natural regeneration is very poor [6,7]. Further, it exhibits large scale mortality or die-back at the seedling stage due to drought [8]. Past records provide evidence of larger distribution of S. robusta forests in the northern and eastern parts of India [9], and their eventual clearance for expanding agriculture, human settlement etc. [10]. During the past decades, there was massive deforestation to use the wood as railway sleepers, ship-building and other load bearing purposes etc., resulting in the decreasing of natural populations in the wild. In addition, Sal forests yield non-timber forest products, including fodder, seed for oil, tannin and gum from bark [11] and leaves for plate making [12], hence it is one of the economically important forest tree species.

The conservation and management of plant species, in addition to ecological information, requires a sound understanding of underlying genetic processes as well as variation within and among populations [13]. Genetic diversity and natural distribution pattern are very important for the introduction and conservation of forest plant species in general and S. robusta in particular. In order to obtain such information, highly sensitive techniques are required, which should be simple, informative and cost efficient. In recent past, isozyme profiling has been used to assess genetic diversity in S. robusta populations of Nepal [14]. However, Biochemical markers such as isozyme and protein patterns, are influenced by the developmental stage of the plant as well as environmental factors; moreover, they offer limited polymorphism and often do not allow discrimination among closely related cultivars [15] and species. Pandey and Geburek [16] have investigated the genetic diversity and structure at fourmicrosatellites of 15 populations of $S$. robusta comprising continuous-peripheral and disjunct-peripheral populations in Nepal._In another study, the same authors have conducted the genetic diversity analysis between adults and juveniles in a semiisolated natural population of S. robusta in Nepal [17]. However, to date no such genetic diversity assessment investigations exists for the $S$. robusta natural tree populations in India.

In order to identify the level of diversity, DNA based molecular marker techniques have become indispensable. Extensive studies have shown that the DNA markers provide highly efficient and informative way to characterize the diversity at population level [18-22]. Widely used PCR-based marker systems are random amplified polymorphic DNA (RAPD), amplified fragment length polymorphism (AFLP), and simple sequence repeats (SSRs) or microsatellites [23,24]. However, in some instances low reproducibility of RAPD [25,26] and high cost of AFLP, and the need to develop species-specific primers for SSR analysis are major limitations, all of which can be overcome by the inter simple sequence repeats (ISSR) markers [27, 28]. ISSR primers of repeat sequences (microsatellites) are reported to be dispersed throughout genomes anchored either at 5' or 3' end with one or few specific nucleotides and amplify the sequences between the two microsatellite loci [29]. Longer primers (16-25 mer) permit the use of high annealing temperatures $\left(45-60^{\circ} \mathrm{C}\right)$, which is probably the reason for the improved reproducibility and reliability of ISSR compared to RAPD where 10-mer primers are used [30].

Currently, no DNA fingerprinting investigation had been carried out to assess the genetic diversity of $S$. robusta populations in India using molecular markers. Therefore, this pioneering investigation aimed at determining the genetic variability assessment within and among different natural $S$. robusta tree populations exists in tropical moist deciduous forest regions in Odisha, India using ISSRs. The outcome of the study is highly useful in designing future conservation strategies for this important dominant tree species.

\section{MATERIALS AND METHODS}

\subsection{Study sites and plant sampling}

Fresh and young leaf samples were collected from four different natural tree populations of S. robusta present in different regions of Odisha, India i.e. Kadukaman of Kalahandi South Forest Division; Athamalik of Hatidara Forest Division; Benmunda and Bandhori of Keonjhar Forest Division; Tamana and Rajin of Khorda Forest Division. Each population was positioned by a Global Positioning System (GPS), and the location details are depicted in Figure-1 and Table-1. In each population, individual's trees were randomly selected for sample collection. In total 100-individual leaf samples from four different populations were collected for the DNA fingerprinting studies. The locations of the populations, climatic conditions and forest type were recorded for each of the populations (Table 1). Morphological characteristics like individual tree height, canopy length and girth diameter were recorded for each of the trees from all four experimental locations.

Table 1: Description of $S$. robusta samples collected from different locations in Odisha, India.

\begin{tabular}{|c|c|c|c|c|c|c|c|}
\hline \multirow[b]{2}{*}{ Population } & \multirow{2}{*}{$\begin{array}{l}\text { Population } \\
\text { code }\end{array}$} & \multirow{2}{*}{$\begin{array}{c}\text { Type of } \\
\text { forest }\end{array}$} & \multirow{2}{*}{$\begin{array}{l}\text { Av. annual } \\
\text { rainfall } \\
(\mathbf{m m})\end{array}$} & \multicolumn{3}{|c|}{ GPS reading } & \multirow{2}{*}{$\begin{array}{c}\text { Number } \\
\text { of } \\
\text { samples }\end{array}$} \\
\hline & & & & Latitude & Longitude & Altitude/elevation & \\
\hline $\begin{array}{l}\text { Kadukaman, Kalahandi } \\
\text { South Forest Division }\end{array}$ & KHD & $\begin{array}{l}\text { Reserve } \\
\text { forest }\end{array}$ & 1378.20 & $19^{\circ} 36^{\prime} .065^{\prime} \mathrm{N}$ & $083^{\circ} 08.726^{\prime} \mathrm{E}$ & $753 \mathrm{~m}$ & 25 \\
\hline $\begin{array}{l}\text { Athamalik, } \\
\text { Hatidara Forest Division }\end{array}$ & ATH & $\begin{array}{c}\text { Reserve } \\
\text { forest }\end{array}$ & 1421.00 & $20^{\circ} 44.182^{\prime} \mathrm{N}$ & $084^{\circ} 40.589^{\prime} \mathrm{E}$ & $343 m$ & 25 \\
\hline $\begin{array}{l}\text { Benmunda and Bandhori, } \\
\text { Keonjhar Forest Division }\end{array}$ & KJR & $\begin{array}{c}\text { Reserve } \\
\text { forest }\end{array}$ & 1534.50 & $21^{\circ} 13^{\prime} .325^{\prime} \mathrm{N}$ & $085^{\circ} 30.518^{\prime} \mathrm{E}$ & $220 \mathrm{~m}$ & 25 \\
\hline $\begin{array}{l}\text { Tamana and Rajin } \\
\text { Khurda Forest Division }\end{array}$ & TMN & $\begin{array}{c}\text { Reserve } \\
\text { forest }\end{array}$ & 1449.10 & $19^{\circ} 53^{\prime} .349^{\prime} \mathrm{N}$ & $084^{\circ} 59.769^{\prime} \mathrm{E}$ & $520 \mathrm{~m}$ & 25 \\
\hline
\end{tabular}




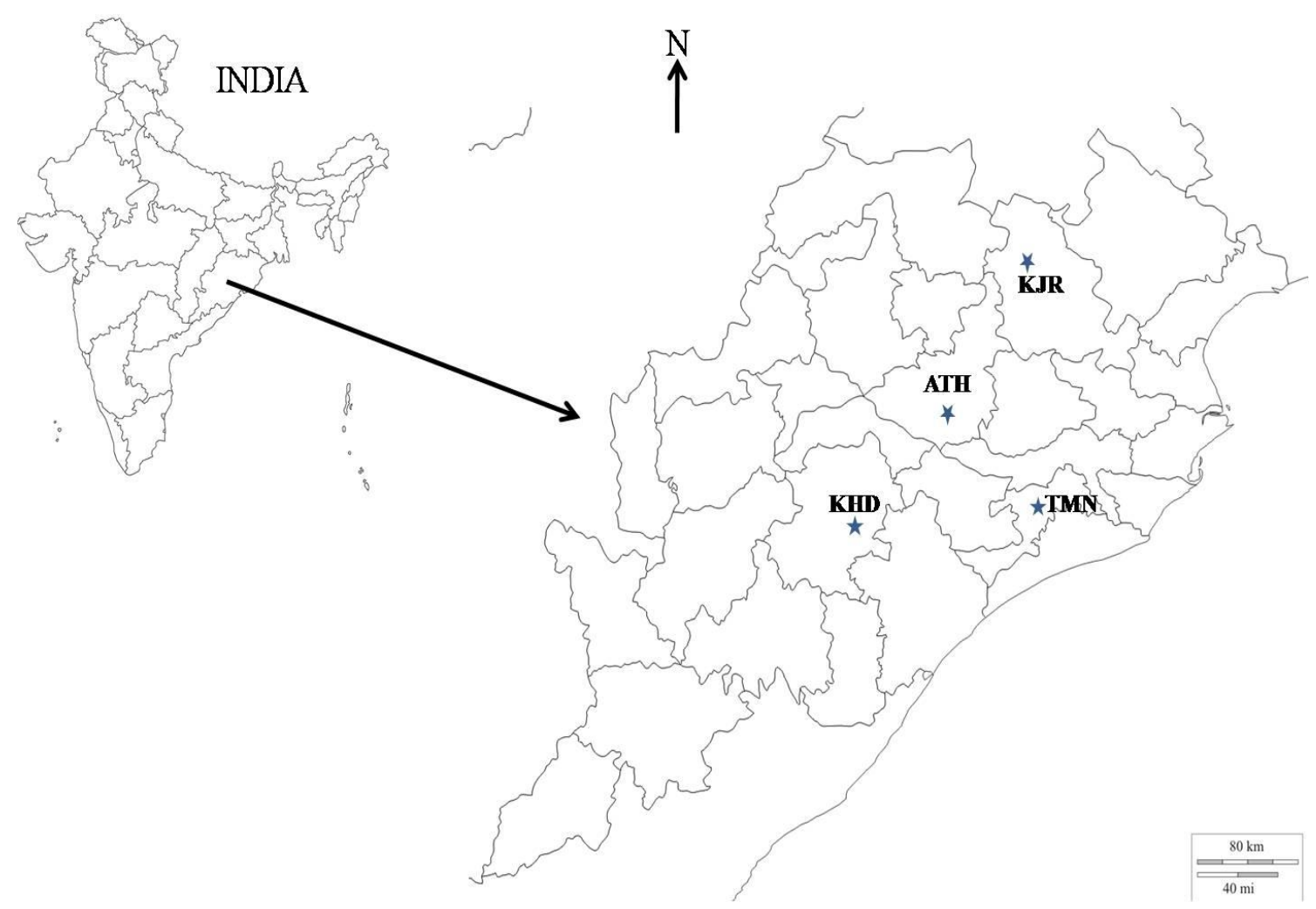

Fig. 1: Map of India showing the sampled populations of S. robusta. KHD, Kalahandi; ATH, Athamalik; KJR, Keonjhar and TMN, Tamana populations.

\subsection{DNA extraction}

One gram of leaf material was ground using liquid nitrogen. Genomic DNA was isolated from approximately $100 \mathrm{mg}$ of finely ground powder using DNeasy Plant Mini Kit (Qiagen, Cat. No 69104) as per the manufacturers recommendations.

The quality of genomic DNA was examined by $0.8 \%$ agarose (w/v) gel electrophoresis and quantified spectrophotometrically at A260 and A280 nm. Each sample was diluted to $50 \mathrm{ng} / \mu \mathrm{l}$ in TE buffer and stored at $-20^{\circ} \mathrm{C}$, until use.

\subsection{ISSR primer screening}

Primers were selected on the basis of their ability to detect distinct, clearly resolved and polymorphic amplified products after screening with $S$. robusta DNA, for further analysis. The primers that gave either negative or weak/complex allele patterns were discarded, while those giving reproducible patterns were adopted for further detailed characterization.

In total, 20-ISSR primers (IDT, India) were screened, and based on the number and reproducibility of the polymorphic fragments, 16-primers were selected for further analysis. The details of primers used are presented in Table- 2 .

\subsection{ISSR-PCR amplification}

PCR amplification reaction for ISSR analysis were conducted in a total volume of $25 \mu \mathrm{l}$ reaction mixture in a $0.2 \mathrm{ml}$ PCR tube which consisted of 50ng of template DNA, 1 $\times$ Taq buffer-A (10 mM Tris-Cl [pH 9.0]), $50 \mathrm{mM} \mathrm{KCl,} 15 \mathrm{mM} \mathrm{MgCl}_{2}$ and $0.1 \%$ gelatin, $100 \mu \mathrm{M}$ of each dNTPs (dATP, dTTP, dCTP and dGTP), 20 $\mu \mathrm{M}$ primer, 5Unit/ $\mu \mathrm{l}$ Taq DNA polymerase (GeNei, India). Amplification was performed in a PTC-100 thermal cycler (MJ Research, Watertown, MA, USA) programed for a preliminary $2 \mathrm{~min}$ denaturation step at $94^{\circ} \mathrm{C}$, followed by 40 cycles of denaturation at $94^{\circ} \mathrm{C}$ for $30 \mathrm{~s}$, annealing at required temperature (depending on Tm of the ISSR primer) for $1 \mathrm{~min}$, extension at $72^{\circ} \mathrm{C}$ for $2 \mathrm{~min}$, and finally extension at $72^{\circ} \mathrm{C}$ for 7 $\min$.

\subsection{Agarose gel electrophoresis and imaging}

Separation of amplified DNA fragments were performed by electrophoresis in $1.8 \%(\mathrm{w} / \mathrm{v})$ agarose gel along with a molecular weight marker (500bp) for comparison, pre-stained with ethidium bromide and visualized under UV light and captured the image by ChemiDoc gel imaging system (Bio-Rad) for further data analysis. 
Table 2: List of ISSR primers, total number of amplified fragments, number of mono- and poly-morphic fragments, and percentage of polymorphism generated in the $S$. robusta.

\begin{tabular}{|c|c|c|c|c|c|c|c|}
\hline $\begin{array}{l}\text { S. } \\
\text { No. }\end{array}$ & Primer sequence (5'-3') & $\begin{array}{l}\text { Length of amplified } \\
\text { alleles (bp) }\end{array}$ & $\mathbf{T}_{\mathbf{m}}$ & $\begin{array}{l}\text { Total no. } \\
\text { of alleles }\end{array}$ & $\begin{array}{c}\text { No. of } \\
\text { monomorphic } \\
\text { alleles }\end{array}$ & $\begin{array}{c}\text { No. of } \\
\text { polymorphic } \\
\text { alleles }\end{array}$ & $\begin{array}{c}\text { Polymorphism } \\
(\%)\end{array}$ \\
\hline 1 & CACACACACACACACARG & $200-1300$ & $52.7^{\circ} \mathrm{C}$ & 5 & 3 & 2 & 40 \\
\hline 2 & TGGACACACACACACAC & $300-1600$ & $47.4^{\circ} \mathrm{C}$ & 8 & 4 & 4 & 50 \\
\hline 3 & ACACACACACACACACC & $450-1500$ & $54.8^{\circ} \mathrm{C}$ & 6 & 1 & 5 & 83.33 \\
\hline 4 & CACACACACACACACAG & $300-1700$ & $53.3^{\circ} \mathrm{C}$ & 9 & 4 & 5 & 55.55 \\
\hline 5 & GAGAGAGAGAGAGAGAYT & $350-1500$ & $52.1^{\circ} \mathrm{C}$ & 6 & 2 & 4 & 66.66 \\
\hline 6 & GAGAGAGAGAGAGAGAYG & $250-1600$ & $52.9^{\circ} \mathrm{C}$ & 12 & 5 & 7 & 58.33 \\
\hline 7 & AGAGAGAGAGAGAGAGYT & $400-2000$ & $50.0^{\circ} \mathrm{C}$ & 9 & 3 & 6 & 66.66 \\
\hline 8 & AGGGCTGGAGGAGGGC & $400-2500$ & $49.8^{\circ} \mathrm{C}$ & 9 & 3 & 6 & 66.66 \\
\hline 9 & AGAGAGAGAGAGAGAGC & $200-3500$ & $52.8^{\circ} \mathrm{C}$ & 6 & 2 & 4 & 66.66 \\
\hline 10 & GAGGGTGGAGGATCT & $450-2400$ & $49.1^{\circ} \mathrm{C}$ & 8 & 3 & 5 & 62.50 \\
\hline 11 & СТСТСТСТСТСТСТСТG & $300-1600$ & $46.8^{\circ} \mathrm{C}$ & 5 & 1 & 4 & 80 \\
\hline 12 & AGAGAGAGAGAGAGAGT & $450-1400$ & $52.4^{\circ} \mathrm{C}$ & 6 & 2 & 4 & 66.66 \\
\hline 13 & ACGGTGTGTGTGTGTGT & $450-1550$ & $54.5^{\circ} \mathrm{C}$ & 9 & 2 & 7 & 77.77 \\
\hline 14 & GAAGAAGAAGAAGAAGAA & $350-1500$ & $43.2^{\circ} \mathrm{C}$ & 7 & 3 & 4 & 57.14 \\
\hline 15 & ACAGACAGACAGACAG & $400-1550$ & $47.4^{\circ} \mathrm{C}$ & 6 & 2 & 4 & 66.66 \\
\hline \multirow[t]{3}{*}{16} & CAGCGACAAG & $450-3000$ & $33.5^{\circ} \mathrm{C}$ & 7 & 4 & 3 & 42.85 \\
\hline & Total & & & 118 & 44 & 74 & 1007.43 \\
\hline & Average per primer & & & 7.375 & 2.75 & 4.625 & 62.96 \\
\hline
\end{tabular}

\subsection{Data scoring and statistical analysis}

The experiments were repeated twice for each of the ISSR primer used, and the clear, reproducible, and scorable allele classes were scored using Quantity One software (Bio-Rad) and were converted into binary data matrices on the basis of their presence (1) or absence (0) in the gel. All the alleles were scored to avoid over/under estimate the diversity [31]. Diffused alleles or alleles revealing ambiguity in scoring were considered as missing data and designated as ' 9 '. Genetic similarity between pairs was calculated according to Jaccard's similarity coefficient (UPGMA), and a dendrogram was generated by using NTSYS-pc version 2.1 software. Analysis of molecular variance (AMOVA) estimated to know the \% polymorphism exists within and among populations of sal. Principal component analysis (PCA) based on Jaccard's similarity was used to estimate the actual number of groups that may be obtained by cluster analysis. Diversity values were calculated according to Nei's unbiased statistics using POPGENE.

\section{RESULTS}

\subsection{ISSR primer polymorphism}

Sampling (consisting 100-adult trees) was carried out in a sal dominated natural moist deciduous forest regions exist within Odisha state, India (Table 1). Out of 20-ISSR primers screened, 16-ISSR primers produced clear, scorable and reproducible DNA allele classes. The 16-ISSR markers amplified a total of 118 alleles and the total number of scored alleles varied from 5 to 12 for different primers, with a mean of 7.37 alleles per primer (Table 2), of which 74 were polymorphic with an average of 4.625 polymorphic alleles per primer. ISSR primer $(\mathrm{GA})_{8} \mathrm{YG}$ yielded the highest number of alleles $\mathrm{s}(12)$ and primers $(\mathrm{CA})_{8} \mathrm{RG}$ and $(\mathrm{CT})_{8} \mathrm{G}$ yielded lowest number of alleles (5) with average allele size between 200-3500bp. The percentage of polymorphism for individual primers ranged from $40 \% \quad\left[(\mathrm{CA})_{8} \mathrm{RG}\right]$ to 83.33\% $\left[(\mathrm{AC})_{8} \mathrm{C}\right]$ (Table 2). The ISSR fingerprinting profile obtained by using the primer 5'-AGGGCTGGAGGAGGGC-3' in ATH population are depicted as Figure-2.

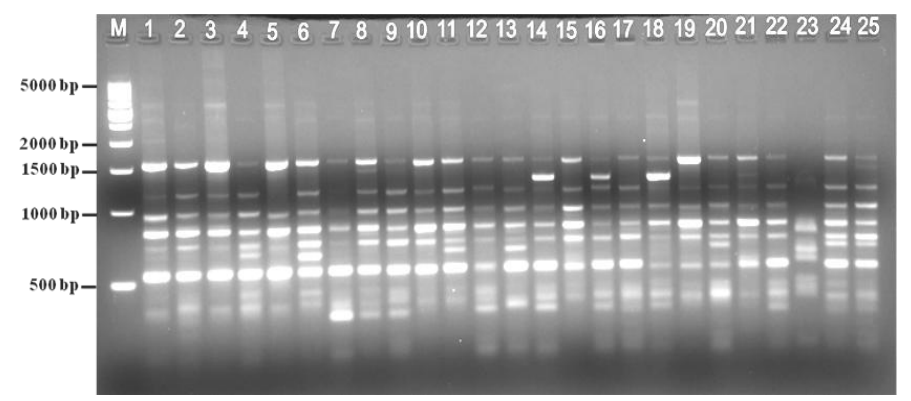

Fig. 2: ISSR fingerprinting profile of 25-individuals of $S$. robusta using primer- 5'-AGGGCTGGAGGAGGGC-3' and ' $\mathrm{M}$ ' is a molecular size marker (500bp).

\subsection{Genetic variation within and among population}

The percentage of polymorphic loci recorded highest for the KJR (86.54\%) and lowest for the ATH (70.51\%) populations, with an average value of $79.32 \%$ (Table 5). The effective number of alleles (Ae) showed variation in the rage of 1.359 (KHD) to 1.404 (KJR and TMN) with a mean of 1.386 , and recorded 1.710 at species level. Nei's gene diversity $(\mathrm{He})$ values ranged from 0.219 (KHD) to 0.251 (TMN) with an average of 0.251 and at species level recorded 0.394. Shannon's information index (Io) observed highest in TMN (0.389) and lowest in ATH (0.333) population with an average value of 0.360 , and at species level recorded 0.573. Further, among the four populations studied, ATH showed lowest level of variability and KJR (0.382), TMN (0.389) exhibited highest variability, respectively. The gene flow (Nm) estimated using ISSRs was low (0.3649) per generation (Table-5). Analysis of molecular variance (AMOVA) showed highly significant $(P<0.001)$ genetic variability among populations and revealed a higher proportion of genetic variability within populations (54.06\%) compared to among population genetic variability (45.94\%) (Table-3). 
Table 3: Analysis of molecular variance (AMOVA) for 100-individuals in four populations of $S$. robusta.

\begin{tabular}{lcccccc}
\hline $\begin{array}{l}\text { Source of } \\
\text { variation }\end{array}$ & d.f. & SSD & MSD & $\begin{array}{c}\text { Est. } \\
\text { Var. }\end{array}$ & $\begin{array}{c}\text { TV } \\
(\boldsymbol{\%})\end{array}$ & $p$-value \\
\hline $\begin{array}{l}\text { Among } \\
\text { population }\end{array}$ & 3 & 1267.28 & 422.42 & 16.13 & 45.94 & $<0.001$ \\
\hline $\begin{array}{l}\text { Within } \\
\text { population }\end{array}$ & 196 & 1822.96 & 18.98 & 18.98 & 54.06 & $<0.001$ \\
\hline Total & 199 & 3090.24 & 441.40 & 35.11 & & \\
\hline
\end{tabular}

df, degree of freedom; SSD, sum of squared deviation; MSD, mean sum of squared deviation; Est. var., estimated variance; TV \%, total variance percentage $p$-value, probability value.

\subsection{Genetic relationship between populations}

The pair wise genetic identity value among the populations ranged from 0.6915 between KHD and KJR to 0.7517 between KHD and ATH, with a mean of 0.7216 (Table-4). Further, genetic distance was higher for TMN and KJR populations (0.3520) and lowest for KJR and KHD populations
(0.0649) (Table-4). The similarity matrix representing Jaccard's similarity coefficient was used for clustering four-populations, adopting UPGMA algorithms similarity matrix. The clustering of different populations based on Jaccard's coefficients presented in Figure-3, and which grouped the populations into two major clusters. Cluster-I represents the KJR sal population alone. Cluster-II again divided into two sub-clusters; these are subcluster-a and sub-cluster-b. Sub cluster-a represents the TMN population alone and the sub-cluster-b represents the ATH and KHD populations, respectively (Figure 3 ). The KJR population is genetically the most distant from all others, followed by TMN. The clustering pattern under study revealed considerable genetic variability within populations. The grouping of sal populations through principal coordinate analysis (PCA) also resulted in similar trends as observed through three-dimensional Principal Coordinate Analysis (Figure-4).

Table 4: Nei's unbiased measures of genetic identity (above diagonal) and genetic distance (below diagonal) between the populations of S. robusta by ISSR.

\begin{tabular}{ccccc}
\hline Populations & KHD & ATH & KJR & TMN \\
\hline KHD & $* * *$ & 0.7517 & 0.6915 & 0.7442 \\
ATH & 0.2855 & $* * *$ & 0.7232 & 0.7243 \\
KJR & 0.0649 & 0.3241 & $* * *$ & 0.7033 \\
TMN & 0.2954 & 0.3226 & 0.3520 & $* * *$ \\
\hline
\end{tabular}

Table 5: Genetic variability within populations of S. robusta detected by ISSR analysis.

\begin{tabular}{|c|c|c|c|c|c|c|}
\hline Population & $\mathbf{A}_{0}$ & $\mathbf{A}_{\mathbf{e}}$ & $\mathbf{H}_{0}$ & $I_{0}$ & $\mathbf{P}(\%)$ & $\mathbf{N m}$ \\
\hline KHD & $1.750(0.43)$ & $1.359(0.35)$ & $0.219(0.18)$ & $0.339(0.25)$ & 75.00 & - \\
\hline ATH & $1.705(0.45)$ & $1.380(0.38)$ & $0.220(0.19)$ & $0.333(0.27)$ & 70.51 & - \\
\hline KJR & $1.865(0.34)$ & $1.404(0.34)$ & $0.246(0.17)$ & $0.382(0.23)$ & 86.54 & - \\
\hline TMN & $1.852(0.35)$ & $1.404(0.32)$ & $0.251(0.16)$ & $0.389(0.22)$ & 85.26 & - \\
\hline Mean & 1.793 & 1.386 & 0.234 & 0.360 & 79.32 & - \\
\hline At species level & 1.980 & 1.710 & 0.394 & 0.573 & 98.08 & 0.3649 \\
\hline SD & 0.13 & 0.28 & 0.12 & 0.15 & & \\
\hline
\end{tabular}

$\mathrm{A}_{\mathrm{O}}$-observed number of alleles, $\mathrm{A}_{\mathrm{e}}$-the effective number of alleles, $\mathrm{H}_{\mathrm{o}}$-Nei's gene diversity,

$\mathrm{I}_{\mathrm{o}}$-Shannons's information index, $\mathrm{P}$-percentage polymorphism, Nm-Gene flow.

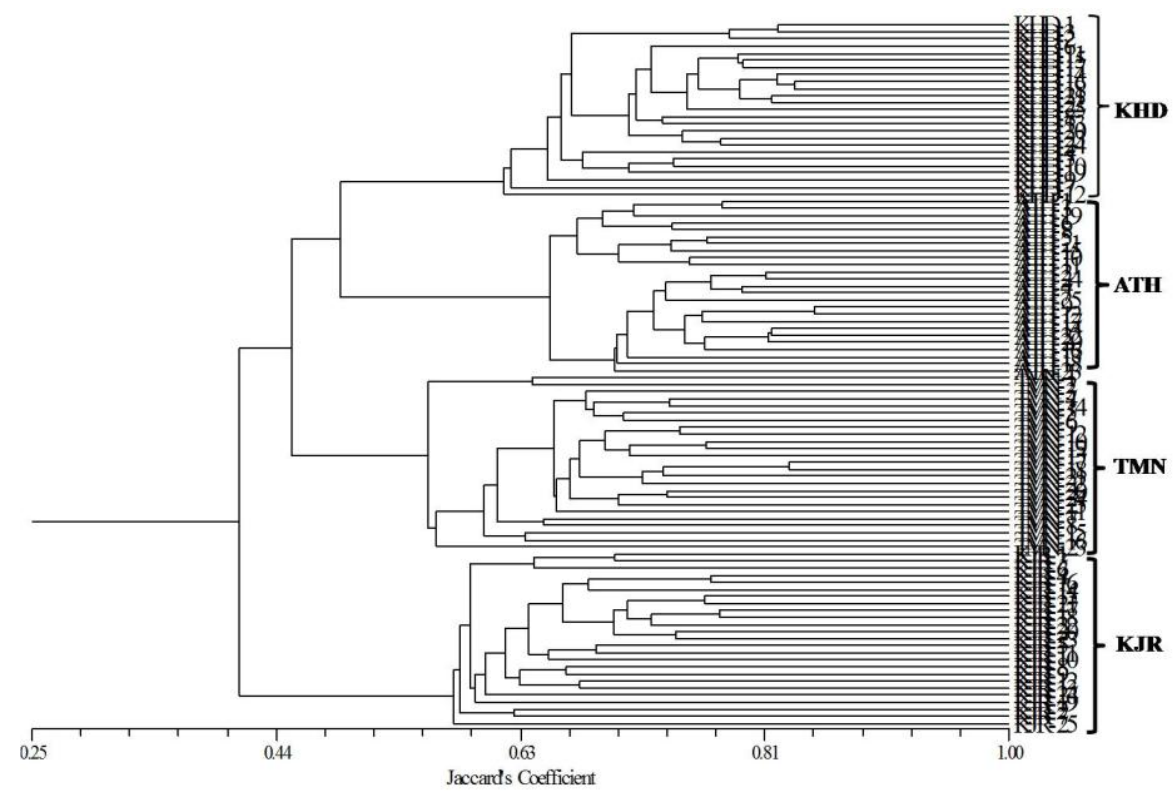

Fig. 3: UPGMA-based dendrogram representing genetic relationships among four-populations of S. robusta based on Jaccard's similarity coefficients. 


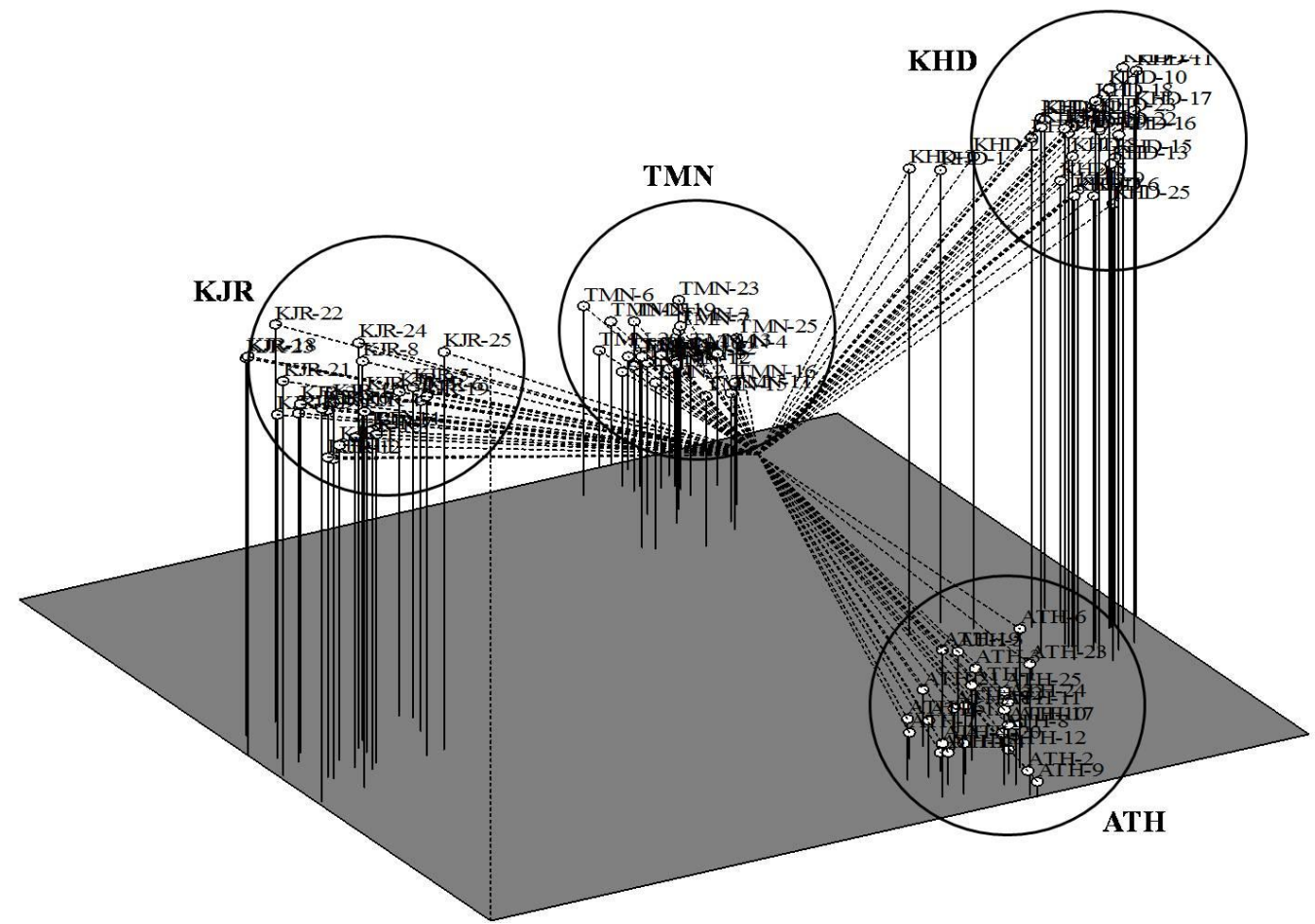

Fig. 4: 3D plot shows distribution of 100-S. robusta tree individuals from four different populations by principal coordinate analysis.

\section{DISCUSSION}

The present study reports genetic variability assessment in different populations of tropical moist deciduous forest tree species, $S$. robusta for the first time in India. In order to analyze genetic diversity, 100-individual tree-DNA samples were subjected to 20-ISSR markers, and based on reproducible, scorable allele classes, 16-primers were considered for further analysis. The tested ISSR primers were allowed the discovery of reasonably high level of polymorphism (average 63\%) and are a reflection of presence of a wide range of genetic variation among the individuals examined. The present findings seem to be relatively similar when compared to the reports of previous ISSR studies on different tree species [32-34]. Our study demonstrates for the first time that the ISSR-PCR a suitable method for detection of genetic variability in sal. The rates of evolution in different parts of the genome are extremely variable, allowing molecular data to be applicable at any taxonomic level. Further, an outstanding advantage of a molecular approach is the immense amount of potential data it provides $[21,32,35,36]$ as evidenced by the current investigation.

The genetic variability (Nei's genetic diversity, ) at population levels were high (0.234) in the present study, as compared to similar studies conducted in different plant species i.e. in Roscoea procera Wall.- 0.166 [20], in Astragalus sericeocanus Gontsch.- 0.112 [22]. However, the level of genetic diversity in the present study was more or less similar to Saraca asoca [19]. Shannon's information index (Io) mean value (0.360) observed in this study was higher than the similar recent studies conducted on different plant species such as in Roscoea procera Wall., 0.263 [20]; in Astragalus sericeocanus Gontsch., 0.173 [22] using ISSRs and in Saraca asoca (Roxb) De Wilde, 0.152 [19] using RAPDs, confirming its (pollen reception from xeno and geitono, and cryptic self-incompatibility) out crossing nature. However, it is argued that long-lived species like sal tree should strongly favor out crossing [37].

The analysis of molecular variance (AMOVA) in the current study revealed a significantly $(<0.001)$ high variance $(54.06 \%)$ within the populations compared to variance that exists among the populations (45.94\%) and our results are in agreement with the trend observed in perennials and long-lived tree species $[19,20]$. The gene flow $(\mathrm{Nm})$ pertains to gene movement across intra- and inter-population levels and Nm largely shows impact on genetic differentiation in populations [34]. The low level of gene flow and high level of inter population differentiation in the present study could be a reflection of limited seed and pollen dispersal and inbreeding nature of $S$. robusta populations. Further, S. robusta being a long-lived tree species has maintained a high genetic diversity. The genetic differentiation among the populations could be the result of an adaptation to environmental gradients. In particular, $S$. robusta is distributed across different eco-geographic conditions with respect to soil composition, altitude etc. which could drive the acquisition of total adaptation. In addition, the genetic diversity of a plant species can be governed by different factors such as distribution range, life form, breeding system, seed dispersal mechanism mode of reproduction and successional status $[38,39]$. Of these, breeding system appears to be the most important factor, followed by life form, seed 
dispersal and successional status [40] It has been reported that a species, which has a long life, high frequency of gene flow and more number of seed, tends to possess high genetic diversity [41]. However, among populations variance value is higher side compared to recent reports on different plant species [19,20], indicating the necessity of enhancing the gene flow among populations by cross-re-introduction of individuals and implementation of in situ conservation of existing populations.

Both UPGMA-phenogram as well as PCA displayed similar grouping of populations. The PCA results corresponded well with the grouping of populations based on cluster analysis. The dendrogram (Jaccard's similarity coefficient) showed highest genetic similarity between populations KHD, ATH and TMN compared to KJR population. The higher genetic similarity indicates that higher probability of origin of all these populations from the same ancestral source, eventually distributed to different locations and also geographically close locations. However, it is true that the higher genetic diversity of the $S$. robusta populations in Odisha, India is largely due to a bigger population size and distribution, and similar reports were observed for different tree populations i.e. in Roscoea procera [20] and in Saraca asoca [19].

\section{CONCLUSION}

In conclusion, the molecular analysis based on an amplification signal using ISSR markers is sufficiently informative and powerful to authentically elucidate genetic variability in $S$. robusta. The ISSR markers reported in the present study will facilitate the understanding of genetic variability, inter-population gene flow and evolutionary relationships in $S$. robusta. The Keonjhar S. robusta population harbor highest genetic diversity thereby deserving higher priority for in situ conservation. Overall high genetic diversity, limited gene flow and genetic differentiation indicates the need for implementing in situ and ex situ conservation of studied $S$. robusta populations.

\section{ACKNOWLEDGMENT}

This work was supported by the research grant to G.K.Surabhi by the Forest and Environment Department, Government of Odisha, India, is gratefully acknowledged. We wish to thank Chief Executive, Regional Plant Resource Centre for facilities.

Conflict of Interests: The authors declare no conflict of interest.

\section{REFERENCES}

1. Ashton PS. Flora malesiana. Series I-Spermatophyta, Flowering plants. vol 9, part 2, Dipterocarpaceae, Martinun Nijhoff Publicatons, The Netherlands; 1982.

2. Tewari DN. A monograph on sal (Shorea robusta), International book distributors. Dehra Dun; 1995.

3. Champion HG, Seth SK. A revised survey of the forest types of India. The manager of publications. Delhi; 1968.

4. Momose K, Yumoto T, Nagamitsu T, Kato M, Nagamasu H, Sakai S, Harrison RD, Itioka T, Hamid AA, Inoue T. Pollination biology in a lowland dipterocarp forest in Sarawak, Malaysia. I. Characteristics of the plant-pollinator community in a lowland dipterocarp forest. Am J Bot. 1998; 85:1477-1501.

5. Jackson JK. Manual of Afforestation in Nepal, Forest Research and Survey Centre, Kathmandu, Nepal; 1994.

6. Pawar GV, Singh L, Jhariya MK, Sahu KP. Regeneration status in relation to anthropogenic disturbance in tropical deciduous forest of Chhattisgarh, The Ecoscan. 2012; 1:281-286.

7. Pattanaik S, Dash A, Mishra RK, Nayak PK, Mohanty RC. Seed germination and seedling survival percentage of Shorea robusta Gaertn. f. in buffer areas of Similipal biosphere reserve, Odisha, India. Journal of Ecosystem Ecography. 2015; 5:1-4.

8. Kandya AK. Seed viability in Sal (Shorea robusta). Journal of Botanical Society. 2006; 41: 16-24.

9. 'O'Malley LSS. Provincial geographies of India: Bengal, Bihar, and Orissa, Sikkim; 2011.

10. Negi SS. Indian forestry through Ages, Indus Publishing Company, New Delhi; 1994, p. 42-43.

11. Narayanamurti D, Das N. A preliminary note on adhesives, building boards, and moulding powder from tree's bark. Indian For. 1951; 77:706-708.

12. Chitale VS, Behera MD. Can the distribution of sal (Shorea robusta Gaertn. f.) shift in the northern direction in India due to changing climate?. Current Science. 2012; 102:1126-1135.

13. Lee SL, Ng KKS, Saw LG, Lee CT, Muhammad N, Tani N, Tsumura Y, Koskela J. Linking the gaps between conservation research and conservation management of rare dipterocarps: A case study of Shorea lumutensis. Biol Conserv. 2006; 131:72-92.

14. Suoheimo $\mathrm{J}, \mathrm{Li} \mathrm{CH}$, Luukkanen O. Isozyme variation of natural populations of sal (Shorea robusta) in the Terai region, Nepal. Silv Genet. 1999; 48:199-203.

15. Jena RC, Samal KC, Pal A, Das BK, Chand PK. Genetic diversity among some promising Indian local selections and hybrids of cashew nut based on morphometric and molecular markers. International Journal of Fruit Science. 2016; 16:69-93.

16. Pandey $M, T$. Geburek T. Genetic differences between continuousand disjunct populations: some insights from sal (Shorea robusta Roxb.) in Nepal. Conserv Genet. 2010; 11: 977-984.

17. Pandey M, Geburek T. Fine-scale genetic structure and gene flow in a semi-isolated population of a tropical tree, Shorea robusta Gaertn. (Dipterocarpaceae). Current Science. 2011; 101: 293-299.

18. Karp A, Edwards K (1998) DNA markers: A global overview in: DNA markers: protocols, applications and overviews, Anolles GC, Gresshoff PM, editors. Willy-Liss Inc, New York; 1998, p.1-14.

19. Senapati SK, Das GK, Aparajita S, Rout GR. Assessment of genetic variability in the Asoca tree of India, Biodiversity. 2012; 13:16-23.

20. Rawat S, Jugran AK, Bhatt ID, Rawal RS, Nandi SK. Genetic diversity analysis in natural populations of Roscoea procera Wall. from West Himalaya, India. Braz J Bot. 2016; 621-630.

21. Sunar S, Yildirim N, Sengul M, Agar G. Genetic diversity and relationships detected by ISSR and RAPD analysis among Aethionema species growing in Eastern Anatolia (Turkey), Comptes Rendus Biologies. 2016; 339(3-4):147-151.

22. Selyutina IY, Konichenko ES, Dorogina OV, Sandanov DV. Genetic diversity of the endangered endemic milkvetch Astragalus sericeocanus Gontsch., Fabaceae from the Lake Baikal region. Biochemical Systematics and Ecology. 2016; 68:163-169.

23. Gupta PK, Varshney RK. The development and use of microsatellite markers for genetic analysis and plant breeding with emphasis on bread wheat. Euphytica. 2000; 113:163-185.

24. Staub JE, Serquen FC, Gupta M. Genetic markers, map construction, and their application in plant breeding. Hort Science. 1996; 31:729739.

25. Halldén C, Hansen M, Nilsson NO, Hjerdin A, Säll T. Competition as a source of errors in RAPD analysis, Theort Appl Genetics. 1996; 93:1185-1192.

26. Hansen M, Halldénand C, Säll T. Error rates and polymorphism frequencies for three RAPD protocols. Plant Molecular Biology Reporter. 1998; 16:139-146. 
27. Gupta M, Chyi YS, Romero-Severson J, Owen JL. Amplification of DNA markers from evolutionarily diverse genomes using single primers of simple-sequence repeats. Theor Appl Genet. 1994; 89:998-1006

28. Zietkiewicz E, Rafalski A, Labuda D. Genomic finger-printing by simple sequence repeat (SSR)-anchored polymerase chain reaction amplification. Genomics. 1994; 20:176-183.

29. Hu Y, Wang L, Xie W, Yang J, Li Y, Zhang H. Genetic diversity of wild populations of Rheum tanguticum endemic to China as revealed by ISSR analysis. Biochem Syst Ecol. 2010; 38: 264-274.

30. Reddy MP, Sarla N, Siddiq EA. Inter simple sequence repeat (ISSR) polymorphism and its application in plant breeding. Euphytica. 2002; 128:9-17.

31. Gherardi M, Mangin B, Goffinet B, Bonnet D, Huguet T. A method to measure genetic distance between allogamous populations of alfalfa (Medicago sativa) using RAPD molecular marker. Theoretical Applied Genetics. 1998; 98:406-412.

32. Feyissa T, Nybom H, Bartish IV, Welander M. Analysis of genetic diversity in the endangered tropical tree species Hagenia abyssinica using ISSR markers. Genet Resour Crop Evol. 2007; 54:947-958.

33. Ballesta P, Mora F, Contreras-Soto RI, Ruiz E, Perret S. Analysis of the genetic diversity of Eucalyptus cladocalyx (sugar gum) using ISSR markers. Acta Scientiarum. 2015; 37:133-140.

34. Liu J, Liao K, Nasir M, Zhao S, Sun Q, Peng X. Analysis of genetic diversity of the apricot germplasm in the southern region of the Tianshan Mountains in Xinjiang, China using the ISSR technique. Eur J Hortic Sci. 2016; 81:37-43.

35. Peterson G, Seberg O (2002) Molecular evolution and phylogenetic application of DMC1, Molecular Phylogenetic Evolution. 2002; 22:43-50.

36. Surabhi GK, Pattanayak S. Deciphering the genetic identity and fidelity of banana through inter simple sequence repeats fingerprinting, Horticultural Biotechnology Research. 2015; 1:16-22.
37. Arroyo MTK, Squeo F. Relationship between plant breeding systems and pollination, In: Kawano, editors. Biological approaches and evolutionary trends in plants, Academic Press, London, 1990, p. 205 227.

38. Hamrick JL, Godt JW. Allozyme diversity in plant species, In: Brown AHD, Clegg MT, Kahler AL, Weir BS, editors. Plant population genetics, breeding, and genetic resources, Sinauer, Sunderland, Mass; 1989, p. 43-63.

39. Bhat KV, Babrekar PP, Lakhanpaul S. Study of genetic diversity in Indian and exotic sesame (Sesamumindicum L.) germplasm using random amplified polymorphic DNA (RAPD) markers, Eupytica. $1999 ; 110: 21-33$.

40. Nybom H. Comparison of different nuclear DNA markers for estimating intraspecific genetic diversity in plants. Mol Ecol. 2004; 13:1143-1155

41. Hamrick JL, Godt JW. Allozyme diversity in plant species, In: Brown AHD, Clegg MT, Kahler AL, Weir BS, editors. Plant population genetics, breeding and genetic resources, Sinauer Associates, Sunderland; 1990, p. 43-63.

\section{How to cite this article:}

Surabhi GK, Mohanty S, Meher RK, Mukherjee AK, Vemireddy LNR. Assessment of genetic diversity in Shorea robusta: an economically important tropical tree species. J App Biol Biotech. 2017; 5 (02): 110-117. DOI: 10.7324/JABB.2017.50218 